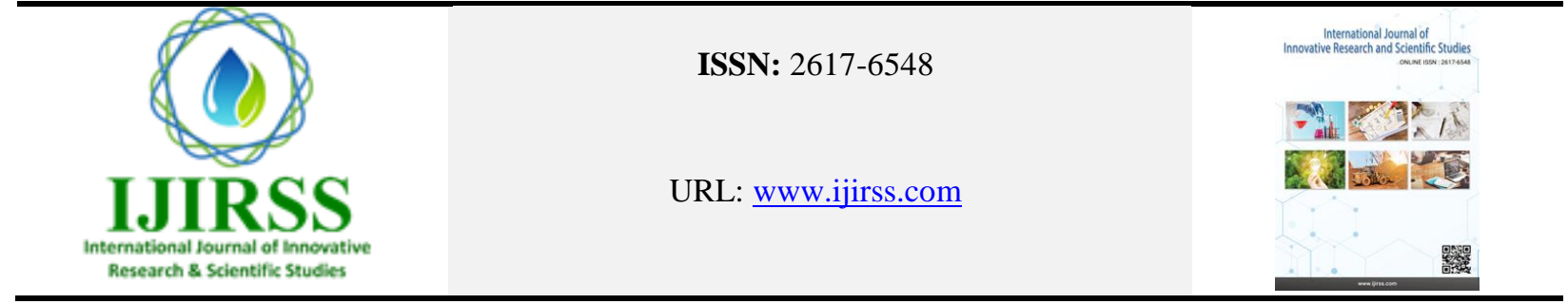

\title{
Influence of Biofertilizer Application Methods on Growth and Yield Performances of Green Pepper
}

\author{
Saidajan Abdiani ${ }^{1}$, Kifayatullah Kakar ${ }^{2,3 *}$, Gulbuddin Gulab ${ }^{1}$, Shafiqullah Aryan ${ }^{2}$ \\ ${ }^{1}$ Horticulture Department, Faculty of Agriculture, Nangarhar University, Nangarhar 2601, Afghanistan \\ ${ }^{2}$ Agronomy Department, Faculty of Agriculture, Nangarhar University, Nangarhar 2601, Afghanistan \\ ${ }^{3}$ Graduate School for International Development and Cooperation (IDEC), Hiroshima University, Higashi-Hiroshima, Hiroshima 739- \\ 8529, Japan \\ *Corresponding author: Kifayatullah Kakar (kifayatullahkakar@gmail.com)
}

\begin{abstract}
Nutrient management is a crucial factor and needs consideration for better growth and high yield of green pepper. An experiment was conducted in the experimental farm of Nangarhar University Faculty of Agriculture to evaluate the influence of different methods of biofertilizer on growth and yield performances of green pepper during 2017. The experiment was conducted with randomized complete block design in five treatments and four replications. The treatments were (1) control, (2) traditional method (TM), (3) root dipping (RD), (4) soil application (SA), and (5) root dipping and soil application (RDSA). Results showed that plant length, branch number, fruit number, and fruit weight were significantly different among treatments. RDSA increased branch and fruit numbers, as well as fruit length, compared to other treatments. RDSA had a greater yield which was 5.4 ton per hectare, followed by TM, SA, RD, and control which were 5.1, 4.7, 4.3, and 3.8 ton per hectare, respectively. Economic analysis of fertilizer's expenses revealed that TM, RDSA, SA, and RD used a huge amount of chemical and biofertilizers. However, RDSA enhanced net income followed by TM, SA, and RD. This research will encourage bnbfarmers to adopt with biofertilizers and decrease the use of chemical fertilizers for eco-friendly forming.
\end{abstract}

Keywords: Green pepper, Biofertilizer, Chemical fertilizer, Eco-friendly, Capsicum annuum, Sustainable agriculture.

DOI: $10.53894 /$ ijirss.v2i4.23

Funding: The authors highly appreciated the Higher Education Development Program (HEDP) for the financial support to this research.

History: Received: 10 June 2019/Revised: 13 August 2019/Accepted: 30 September 2019/Published: 21 October 2019

Licensed: This work is licensed under a Creative Commons Attribution 4.0 License $($ (c) $)$ Er

Acknowledgement: All authors contributed to the conception and design of the study.

Competing Interests: The authors declare that they have no conflict of interests.

Transparency: The authors confirm that the manuscript is an honest, accurate, and transparent account of the study was reported; that no vital features of the study have been omitted; and that any discrepancies from the study as planned have been explained.

Ethical: This study follows all ethical practices during writing.

\section{Introduction}

Green pepper (Capsicum annuиm L.) is one of the important vegetable crops which widely cultivated in the temperate, tropical, and sub-tropical countries [1]. It is used as a spice and a source of medicines in pharmaceutical industries [2]. Pepper is considered as one of the principle sources of vitamin $\mathrm{C}$ and is extensively used in dishes, sauces, ketchup, pickles, 
etc $[3,4]$. Nutrient management and fertilizers application are crucial factors affecting growth and yield performances of green pepper [1, 4]. Farmers apply a huge amount of chemical fertilizers to obtain high yield [4]. However, such fertilizers are expensive [3] and are not eco-friendly [5]. Thus, attention is needed to increase pepper productivity through nutrient use efficiency and eco-friendly strategies. Dincheva, et al. [6] suggested that the method, type, and rate of fertilizers should be considered beside crop yield. Application of chemical fertilizers alone decreased fruit quality of pepper Talukder [7]. Mondal, et al. [8] stated that continuous and inappropriate use of chemical fertilizers decline soil fertility and nutrient absorption efficiency, consequently, decrease crop productivity. Among plant nutrient sources, biofertilizers are low cost, renewable and effective. Beneficial bacteria, fungal, and blue-green alga of biofertilizers promote plants growth through producing auxins, gibberellins, cytokinins, etc and improve nutrients absorption in the soil [9]. They are eco-friendly and lead the way for high yield, quality product as well as fertilizer use efficacy [10].

Biofertilizers contain nitrogen fixation and phosphorus solubilizer bacteria, etc, which can affect seed germination, root growth and so on [1]. An integrated nutrient management system is required to maintain soil quality and obtain a high yield. The aim of the current study is to evaluate the influence of different application methods of biofertilizer combined with chemical and organic fertilizers on growth and yield performances of green pepper.

\section{Materials and Methods}

\subsection{Site Selection And Experimental Design}

An experiment was conducted at the experimental field of Nangarhar University Faculty of Agriculture in 2017. The experiment was conducted with randomized complete block design in five treatments and four replications. The treatments were control, a traditional method (TM), and three methods of biofertilizer including (1) rood dipping (RD), soil application (SA), and root dipping and soil application (RDSA). Biofertilizer was a manufacturer of Green Life Bioscience, Bogor, Indonesia. It contained nitrogen fixation, phosphorus solubilizer, and plant growth promoter bacteria with $40 \times 109$ colony-forming unit. Biofertilizer was diluted with distilled water in a 1:100 (v/v) combination based on the recommendation from the manufacturer.

The experimental field was plowed with a chisel plow and raised beds were prepared. Soil properties of the experimental field at $30 \mathrm{~cm}$ depth are illustrated in Table 1 as reported by Abdiani and Kakar [11]. Hydrometer method by soil triangle was conducted to determine soil texture particles. Soil $\mathrm{pH}$ was recorded by a pH meter $(6173 \mathrm{pH}$ meter, Jenco Co., Taiwan). Electroconductivity was measured using an EC meter (3251 COND/SAL/TEMP meter, Jenco Co., Taiwan). Soil phosphorus was quantified by spectrophotometer (SP-300, spectrophotometer, Optima, Co., Japan), and potassium was quantified with a flame photometer (PFP 7, flame photometer, Jenway Co., UK). Finally, the calcium carbonate was tested with the method described by Rowell [12].

Table-1.

Soil characteristics of Nangarhar University faculty of agriculture research farm.

\begin{tabular}{l|l}
\hline Soil properties & Description and quantity \\
\hline Texture Class & Sandy clay loam \\
\hline Clay texture & $25.02 \%$ \\
\hline Silt texture & $27.30 \%$ \\
\hline Sand texture & $47.68 \%$ \\
\hline $\mathrm{pH}$ & 7.8 \\
\hline Electroconductivity & $0.045 \mathrm{dS} / \mathrm{m}$ \\
\hline Total Nitrogen & $1.20 \%$ \\
\hline Phosphorus & $3.3 \mathrm{mg} / \mathrm{kg}$ \\
\hline Potassium & $118 \mathrm{mg} / \mathrm{kg}$ \\
\hline Calcium carbonates & $23.00 \%$ \\
\hline
\end{tabular}

Each treatment received an equal amount of farmyard manure (FYM) and Diammonium phosphate (DAP) except of the control; however, urea and biofertilizer were used based on treatments application as shown in Table 2. The plot size was $12 \mathrm{~m}^{2}$ and contained two raised beds. FYM and DAP were applied as a basal dressing during land preparation. Urea was used at three growing stages (as a basal dress at land preparation, as a top dress after transplanting and at flowering stages). Seedlings of RD treatment were treated with biofertilizer before transplanting.

Table-2.

Sources and amounts of fertilizers applied in each plot of treatments

\begin{tabular}{l|l|l|l|l}
\hline Treatments & FYM $(\mathbf{k g})$ & DAP $(\mathbf{g})$ & Urea $(\mathbf{g})$ & Biofertilizer $(\mathbf{m L})$ \\
\hline Control & 0 & 0 & 0 & 0 \\
\hline TM & 30 & 130 & 260 & 0 \\
\hline RD & 30 & 130 & 0 & 5 \\
\hline SA & 30 & 130 & 0 & 15 \\
\hline RDSA & 30 & 130 & 0 & 20 \\
\hline \multicolumn{2}{r|}{ Note: The presented values are per plot during all growing period. RDSA mean RD (5) and SA (15). }
\end{tabular}




\subsection{Plant Materials and Measurements}

Green pepper (Capsicum annum L.) cv. Sindhi, the most cultivated variety of green pepper in the eastern region of Afghanistan was selected as a test crop. Seeds were sown in nursery boxes and 30 days old seedlings were transplanted to the prepared raised beds. $30 \mathrm{~cm}$ space between crops and $50 \mathrm{~cm}$ between rows were considered as a planting density. During the productive stage, fruits were collected 8 times from each treatment at weekly interval and the yield was calculated. Weeds were controlled three times manually by hands and irrigation was conducted based on weather condition and plant requirement. Growth and yield parameters including plant length, branch and fruit number, fruit length, weight, and diameter as well as yield were recorded. Plant length was randomly recorded on 10 plants with a common ruler from the surface of the soil to the tip of the plant. 20 fruits were randomly selected to evaluate fruit length, diameter, and weight. Economic analysis was also conducted among treatments. SPSS 13.0 statistical software (Prentice Hall, New Jersey, USA) was used to analyze the data. Analysis of variance (ANOVA) was conducted to express the differences among treatments, followed by tukey's multi-comparison test. Significant differences were defined at $p<0.05$ probability level.

\section{Results and Discussion}

\subsection{Growth and Yield Performances}

Growth and yield performances in terms of plant length, branch number, fruit number, and weight were significantly different $(p<0.05)$ among treatments; however, fruit length and diameter did not differ Table 3.

Table-3.

Growth parameters influenced by biofertilizer and other treatments

\begin{tabular}{|c|c|c|c|c|c|c|}
\hline Treatments & $\begin{array}{ll}\begin{array}{l}\text { Plant length } \\
(\mathrm{cm})\end{array} & \\
\end{array}$ & $\begin{array}{l}\text { Branch } \\
\text { number }\end{array}$ & $\begin{array}{l}\text { Fruit } \\
\text { number }\end{array}$ & $\begin{array}{ll}\begin{array}{l}\text { Fruit } \\
(\mathrm{cm})\end{array} & \text { length } \\
\end{array}$ & $\begin{array}{ll}\begin{array}{l}\text { Fruit } \\
(\mathrm{cm})\end{array} & \text { diameter } \\
\end{array}$ & $\begin{array}{l}\text { Fruit weight } \\
\text { (g) }\end{array}$ \\
\hline Control & $34.5 \mathrm{~d}$ & $14.9 \mathrm{~d}$ & $16.8 \mathrm{~d}$ & 8.6 & 1.4 & $1.7 \mathrm{~b}$ \\
\hline TM & $37.8 \mathrm{a}$ & $19.8 \mathrm{a}$ & $25.0 \mathrm{a}$ & 8.9 & 1.5 & $1.9 \mathrm{a}$ \\
\hline $\mathrm{RD}$ & $35.3 \mathrm{~d}$ & $15.2 \mathrm{~d}$ & $17.5 \mathrm{~d}$ & 8.7 & 1.4 & $1.7 \mathrm{~b}$ \\
\hline SA & $36.9 \mathrm{~b}$ & $18.6 \mathrm{~b}$ & $22.3 \mathrm{~b}$ & 8.9 & 1.5 & $1.9 \mathrm{a}$ \\
\hline RDSA & $37.6 \mathrm{a}$ & $20.1 \mathrm{a}$ & $26.7 \mathrm{a}$ & 9.1 & 1.5 & $1.9 \mathrm{a}$ \\
\hline
\end{tabular}

RDSA treatment increased branch number (20.1), fruit number (26.7), and fruit length (9.1) compared to the other treatments; however, TM treatment obtained a higher plant length which was 37.8. Control treatment decreased all growth parameters and showed lower performances. Based on the growth characteristics, RDSA recorded the highest followed by TM, SA, RD, and control, respectively. Biofertilizers promote plant growth and nutrient absorption from the soil, as well as strengthen crops against biotic and abiotic stress [13]. They have nitrogen fixation and phosphorus solubilizing bacteria beside plant growth promoters Pariari and Khan [14]. Khan, et al. [15] reported that biofertilizers can positively affect seed germination, root growth, and nutrient absorption in several crops. Therefore, in this study, the growth performance of RDSA was higher than that in TM which might be due to enhanced uptake of nutrients by the plants.

Yield performance was also significantly different $(p<0.05)$ among treatments Figure 1. RDSA treatment obtained a high yield compared to other treatments which was 5.4 ton per hectare. The lowest yield was recorded in control treatment and was 3.8 ton per hectare. TM, SA, and RD produced 5.1, 4.7, and 4.3 ton per hectare, respectively. Mishra, et al. [16] mentioned that biofertilizer can increase crop yield up to 10-30\% and can decrease the application rate of chemical fertilizer up to $30-40 \%$. Our study also clarified that biofertilizer especially RDSA treatment obtained the highest yield and is a good alternative for chemical fertilizer.

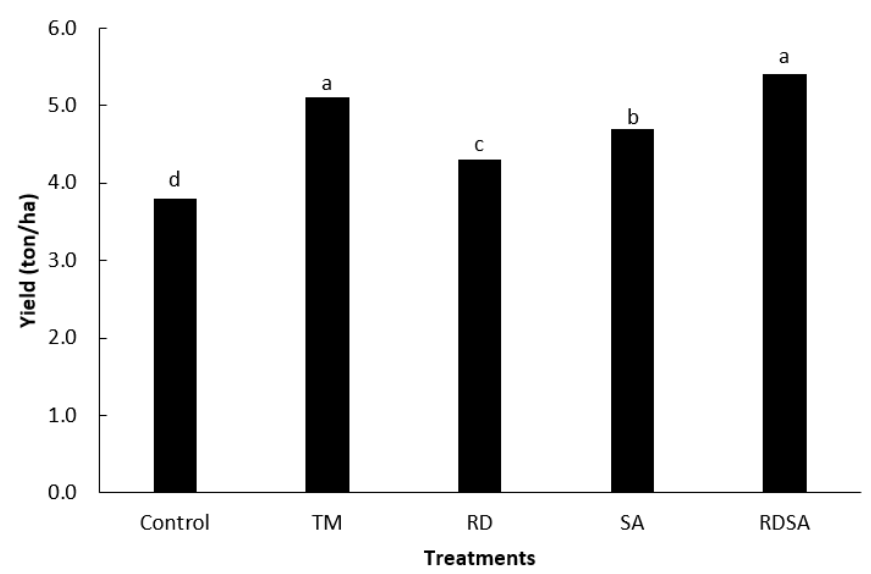

Figure-1.

Yield performance among treatments. TM (traditional method), RD (root dipping), SA (soil application), and RDSA (root dipping and soil application). Similar letters indicate not significant differences. 
Application of phosphorus solubilizing biofertilizer has been declared as a yield improver in several crops [1]. The increased yield in RDSA treatment might be due to improved vegetative growth, maximum fruit number, and fruit length. A similar finding was reported by Ghoname and Shafeek [17]. In addition, the applied chemical fertilizers are not totally absorbed by the plants and will run away from root zones. Such condition will seriously affect the economy of farmers as well as pave the way for pollution of several types particularly groundwater contamination. Consequently, soil fertility will be decreased, and the living organism of the soil and water will face dangerous [18].

\subsection{Economic Analysis}

As mentioned above, RDSA and TM obtained a high yield in contrast to remaining treatments, but TM received a huge amount of chemical fertilizer. Based on the chemical and biofertilizers expenses, TM was an expensive treatment followed by RDSA, SA, RD, and control, respectively.

Table-4.

Economic analysis among treatments based on fertilizer expenses per hectare

\begin{tabular}{l|l|l|l|l|l}
\hline Treatments & Fertilizer expenses & Price of 1kg GP & Yield (ton/ha) & Gross income & Net income \\
\hline Control & 0 & 35 & 3.8 & 133000 \\
\hline TM & 7584 & 35 & 5.1 & 133000 \\
\hline RD & 1875 & 35 & 4.3 & 170916 \\
\hline SA & 5625 & 35 & 4.7 & 150500 & 148625 \\
\hline RDSA & 7500 & 35 & 5.4 & 158875 \\
\hline
\end{tabular}

Note: Economic analysis was conducted only for urea and biofertilizer, the other parameters were not considered. Value are presented in Afghan currency (AFN) (1 AFN = 0.013 US \$). GP indicates green pepper.

According to the market prices, if $1 \mathrm{~kg}$ of urea calculates at $35 \mathrm{AFN}, 1 \mathrm{~kg}$ of green pepper at $35 \mathrm{AFN}$, and $1 \mathrm{~L}$ of biofertilizer at $450 \mathrm{AFN}$, the gross and net income will be the same as illustrated in Table 4 . The comparative economic analysis among different treatments revealed that RDSA is the most profitable treatment followed by TM, SA, RD, and control. Thus, it is clear that RDSA obtained higher net income followed by TM, SA, RD, and control. The uses of chemical fertilizers were enhanced with the green revolution. A few decades ago, it revealed that such fertilizers can hazardous environment for the living organisms. They are not economic and can reduce soil productivity and quality [18].

\section{Conclusion}

In modern agriculture, nutrient management and fertilizers application are the most crucial factors which affecting plant growth, yield, and quality performances. Fertilizers application particularly the use of chemical fertilizers must be considered to prevent environmental problems. The current study revealed that the application of biofertilizer as a root dipping and soil application (RDSA) can compensate for the use of chemical fertilizer. It means that the applied amount of chemical fertilizer might not be absorbed by the plants and might lead the way for environmental pollution caused by chemicals. Further research should be undertaken to point out new application methods and an appropriate amount of fertilizer application based on crop type, soil and region condition.

\section{References}

[1] H. Kumbar, R. A. Chandini, and J. K. Hore, "Effect of biofertilizers and inorganic fertilizers on growth and yield of chilli (Capsicum annuum L.), Int. J. Curr. Microbiol," Applied Sciences, vol. 6, pp. 1564-1568, 2017.Available at: https://doi.org/10.20546/ijcmas.2017.607.187.

[2] M. Berova, G. Karanatsidis, K. Sapundzhieva, and V. Nikolova, "Effect of organic fertilization on growth and yield of pepper plants Capsicum annuum L," Folia Horticulturae, vol. 22, pp. 3-7, 2010.Available at: https://doi.org/10.2478/fhort-2013-0143.

[3] B. H. Naik and R. M. Hosamani, "Influence of azospirillum on growth and yield of green chilli (Capsicum annum L.) cv. Byadagi dabbi at different nitrogen levels, Karnataka," The Journal of Agricultural Science, vol. 6, pp. 108-112, 2003.

[4] G. Gulab, S. A. Abdiani, K. Kakar, and S. Aryan, "Effects of urea foliar application on growth and yield of green pepper," Int. J. Innovative Res. and Sci. Studies, vol. 2, pp. 25-30, 2019.

[5] G. H. Peyvast, P. K. Ramezani, S. Tahernia, Z. Nosratierad, and J. A. Olfati, "Municipal solid waste compost increased yield and decreased nitrate amount of broccoli (Brassica oleracea var. Italica)," J. Appl. Horticulture, vol. 10, pp. 129-132, 2008.Available at: https://doi.org/10.37855/jah.2008.v10i02.27.

[6] Z. Dincheva, I. Dimov, and H. Boteva, "Influence of bioproducts on green pepper yield, average early production. Collection of Reports from the VIIth National Conference with international participants," Plovdiv, pp. 203-208, 2008.

[7] B. Talukder, "Studies on effects of biofertilizers on growth, yield and quality of chili (Capsicum annuum L.). Center for advanced studies on crop management," Ph.D. Thesis, Pundibari, Coock Behar, West Bengal, 2007.

[8] T. Mondal, P. Ghanti, B. Mahato, A. R. Mondal, and U. Thapa, "Effect of spacing and biofertilizer on yield and yield attributes of direct sown Chilli (C. annuum L.) cv," Bona Lanka. Env. Eco, vol. 21, pp. 712-715, 2003.

[9] A. Boraste, K. Vamsi, A. Jhadar, Y. Khairnar, N. Gupta, S. Trivedi, P. Patil, G. Gupta, M. Gupta, K. Hujapara, and B. Joshi, "Biofertilisers: A novel tool for agriculture," Int. J. Microbiol. Res, vol. 1, pp. 23-31, 2009.

[10] B. N. Patel, M. P. Solanki, S. R. Patel, and J. R. Desai, "Effect of biofertilizers on growth, physiological parameters, yield and quality of brinjal cv. Swati Ravaiya," Indian J. Hort, vol. 68, pp. 370-374, 2011.

[11] S. Abdiani and K. Kakar, "Effects of different field crops cultivation on soil physical and chemical properties," Poha, Nangarhar University, vol. 63, pp. 87-91, 2017.

[12] D. L. Rowell, "Soil science: Methods and application," Journal of the Science of Food and Agriculture, vol. 66, pp. 513-576, 1994. 
[13] D. Bhardwaj, M. W. Ansari, R. K. Sahoo, and N. Tuteja, "Biofertilizers function as key player in sustainable agriculture by improving soil fertility, plant tolerance and crop productivity," Microbial Cell Factories, vol. 13, p. 66, 2014.Available at: https://doi.org/10.1186/1475-2859-13-66.

[14] A. Pariari and S. Khan, "Integrated nutrient management of chilli (capsicum annuum L.) in gangetic alluvial plains," Journal of Crop and Weed, vol. 9, pp. 128-130, 2013.Available at: https://doi.org/10.4038/suslj.v16i1.7715.

[15] Z. Khan, S. A. Tiyagi, I. Mahmood, and R. Rizvi, "Effects of N fertilisation, organic matter, and biofertilisers on the growth and yield of chilli in relation to management of plant-parasitic nematodes," Turkish Journal of Botany, vol. 36, pp. 73-81, 2012.

[16] J. Mishra, J. Prakash, and N. K. Arora, "Role of beneficial soil microbes in sustainable agriculture and environmental management," Climate Change and Environmental Sustainability, vol. 4, pp. 137-149, 2016.Available at: https://doi.org/10.5958/2320-642x.2016.00015.6.

[17] A. Ghoname and M. R. Shafeek, "Growth and productivity of sweet pepper (capsicum annum L.) grown in plastic house as affected by organic, mineral and bio-N-fertilisers," J. Agronomy, vol. 4, pp. 369-372, 2005.Available at: https://doi.org/10.3923/ja.2005.369.372.

[18] U. A. Naher, R. Othman, and Q. A. Panhwar, "Culturable total and beneficial microbial occurrences in long-term nutrient deficit wetland rice soil," Australian Journal of Crop Science, vol. 7, pp. 1848-1853, 2013. 